\title{
Human capital, age and job stability: evidence from Spanish certified auditors (1976-1988)
}

\author{
Nieves Carrera, Salvador Carmona, Isabel Gutiérrez*
}

\begin{abstract}
During the period 1976 1988, Spain witnessed pervasive transformations that led the country from a military dictatorship to a fully fledged democracy. In turn, the audit profession experienced high demand which doubled the number of members of the Institute of Sworn Auditors of Spain (Instituto de Censores Jurados de Cuentas de España). In this unique social laboratory, we draw on the insights of human capital theory and the entrepreneurship literature to examine the profile of newly certified auditors at the time of receiving the audit cer tificate that enabled them to (i) become a licensed auditor and engage in public practice, or (ii) become an unli censed auditor and leave the profession immediately after receiving the professional qualification. Our results indicate that those Spanish auditors who had high general or specific human capital and job stability and were at the younger or older ends of the age continuum were less likely to apply for audit licences than their counterparts (i.e. low general or specific human capital, middle aged, and unstable jobs).
\end{abstract}

Keywords: auditors; audit market; human capital theory; entrepreneurship; Spain

\section{Introduction}

Following the end of General Franco's dictatorship in November 1975, Spain witnessed '... the most rapid and pervasive transformations, with no aspect of social, economic and political life remaining untouched.' (Bougen and Vázquez, 1997: $3)$. These transformations impinged on the audit market, which experienced high growth amid the steady process of deregulation and professional reforms that culminated in the enactment of the Spanish Audit Law in 1988 (Bougen, 1997; García-Benau et al., 1998, 1999). The reforms created a 'new' and modern auditing profession and played an instrumental role in the booming de-

\footnotetext{
*Nieves Carrera and Isabel Gutiérrez are professors at Carlos III University, Madrid, and Salvador Carmona is Professor of Accounting at Instituto de Empresa Business School, Madrid. The authors would like to thank the Instituto de Censores Jurados de Cuentas de España for providing access to the requisite data, the conference attendees at the $7 t h$ Raymond Konopka Workshop, the 24th Annual Congress of the European Accounting Association, and the 7th Interdisciplinary Perspectives on Accounting Conference, as well as seminar participants at the University of Manchester who helped them with suggestions on an earlier version of this paper. The helpful comments of Theresa Hammond, Linda Kirkham, Kurt Pany, Keith Robson, Linda Ruchala, Joseph Schultz, Stephen P. Walker are gratefully acknowledged. They would also like to thank the ABR editor, Pauline Weetman, and the two anonymous referees for their many insightful sug gestions. This research is partly funded by the CICYT's (Spain) project SEC 200408176 C02 01 and SEC03 3797. Please address correspondence to Salvador Carmona, Instituto de Empresa Business School, Calle Pinar 15 1B, 28006 Madrid (Spain). E mail: salvador.carmona@ie.edu.

This paper was accepted for publication in March 2008.
}

mand for audit services in Spain during the period 1976-1988. From its inception in 1942 until 1976, the Institute of Sworn Auditors of Spain (Instituto de Censores Jurados de Cuentas de España (ICJCE)) had registered 2,626 newly certified auditors. This figure doubled $(5,255)$ in just 13 years (1976-1988). This situation, characterised by a mix of regulatory uncertainty and strong job market prospects, constitutes a unique social laboratory in which to examine the profile of newly certified auditors.

As in many other countries (e.g. France: Margerison and Moizer, 1996), the audit profession in Spain is separate from the accounting profession. In this setting, audit certification constitutes a prerequisite for applying for an audit licence and becoming a 'licensed auditor' (Ramírez, 2001). ${ }^{1}$ During the observation period, to earn an audit certificate and become a newly certified auditor of the ICJCE, a person needed to: (i) be a Spanish citizen; (ii) be 18 years of age or older; and (iii) hold a university degree or equivalent. In addition, there were requirements to have: (iv) passed a series of qualification exams, which include subjects such as financial accounting, management accounting, finance, and auditing; and (v) never been convicted of a crime. Importantly, the ICJCE's by-laws approved in 1943 did not include professional experience as a prerequisite for receiving the audit certificate. Upon meeting these

\footnotetext{
${ }^{1}$ This is equivalent to the concept of 'responsible individu als' found in the UK.
} 
Figure 1

The process for engaging in audit practice

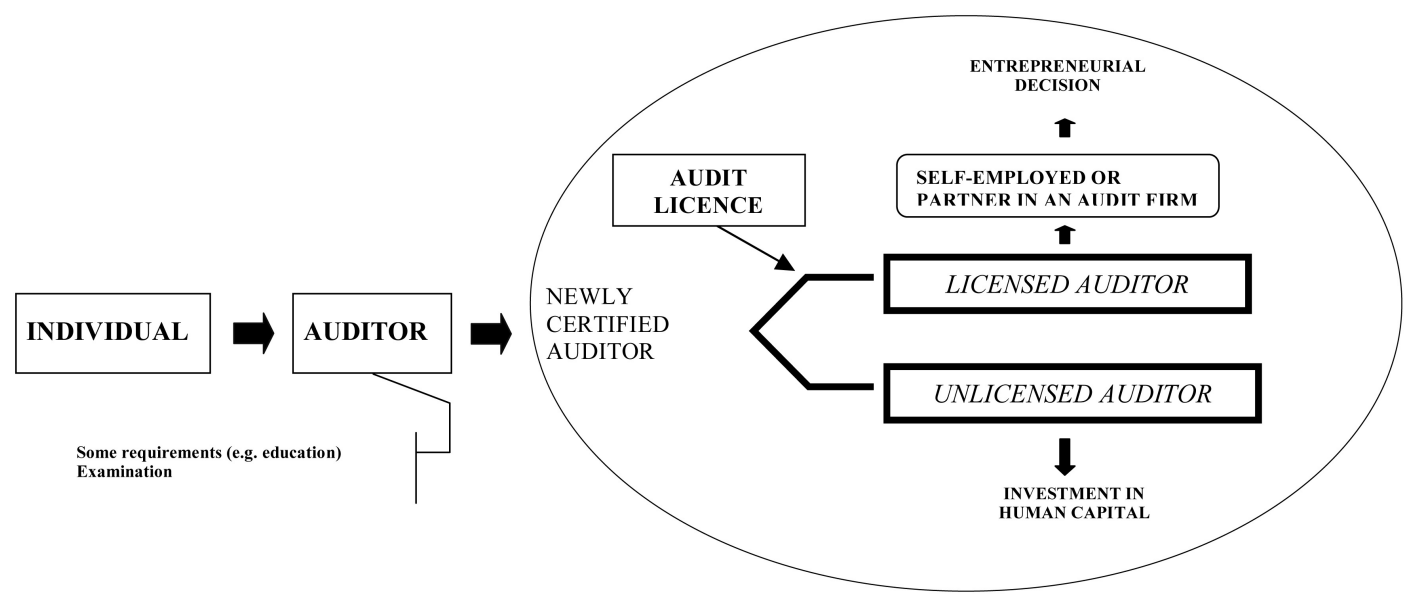

requirements, successful candidates were granted an auditing certificate and gained membership into the ICJCE. Newly certified auditors, therefore, could then either apply for an auditing licence that would enable them to sign audit reports (ejercientes; licensed auditors) or register as an unlicensed auditor (no ejercientes; unlicensed auditors) (see Figure 1). Our study focuses on a specific point in the auditor's life (Carroll and Mosakowski, 1987): the point at which newly certified auditors decided whether to apply for an auditing licence. 'Unlicensed auditors' could leave the profession and obtain work in other sectors (e.g. public sector, academia, and industry), or perform support activities in consultancy and auditing firms. None of these activities required them to hold an audit licence (see Figure 1). At that point in time, we compare the individual profile of 'licensed' versus 'unlicensed' auditors.

Licensed auditors (i) must be on file in the official tax register of the Ministry of Finance as a freelance auditing professional, and (ii) must have obtained acceptable insurance coverage for professional indemnity. Licensed auditors offer their professional services either as self-employed auditors or as partners in auditing firms. In this manner, they become business owner-managers in the audit market and, therefore, they are 'first and foremost ... entrepreneurs trying to make a successful living by providing a service' (Higson, 1997: 203). As noted by Ramírez (2001), sole proprietorships become instrumental organisational forms in the earliest stages of the audit profession, suggesting that individuals applying for an audit licence usually intend to become sole practitioners or partners in an auditing firm (Dillard and Ferris, 1989: 224). In turn, this implies that they are putting their personal wealth and human capital at stake (DeAngelo, 1981: 25).

In this study, we focus on the relationship between certain individual characteristics of newly certified auditors, such as education, age, and job stability, and their decision to become business owner-managers in the audit market during the period 1976-1988. Lafuente and Salas (1989: 18) showed that the personal characteristics of business owner-managers '.. are relevant factors in the study of entrepreneurship, because they will lie behind the supply side of entrepreneurial activities and will have to be closely identified in any public policy oriented to promote such activities.' Consequently, our study focuses on the individual auditor as a unit of analysis. In this manner, this investigation adds to prior research embracing a macro-perspective on the emergence and evolution of the audit profession in continental European countries and, therefore, focuses on professional associations or the profession at large (e.g. Belgium: De Beelde, 2002; Czech Republic: Seal et al., 1996; France: Ramírez, 2001; Germany: Evans and Honold, 2007; Greece: Caramanis, 2002). On rare occasions, these studies surveyed the opinions of auditors and financial executives to outline the impact of liberalisation reforms on auditor behaviour (Caramanis, 1998). As noted by Bröcheler et al. (2004), individual auditors are the most significant asset in the audit market and, therefore, it is apposite to examine the individual characteristics of those engaging in public practice vis-à-vis their counterparts breaking from the pro- 
fession immediately after earning the necessary credentials.

Our examination of the individual traits of newly certified auditors draws on an integration of human capital theory and the entrepreneurship literature. The theory of human capital has highlighted some of the individual determinants of entrepreneurship (e.g. Carr, 1996), such as the effects of the founder's human capital on organisational performance, including the case of auditing firms (e.g. Preisendörfer and Voss, 1990; Pennings et al., 1998; Bröcheler et al., 2004). A basic tenet of human capital theory is that individuals spend time and money on themselves for the sake of future pecuniary and non-pecuniary returns (Blaug, 1976), thereby increasing their specific or general human capital (Becker, 1975). General human capital refers to the acquisition of comprehensive formal education and training, such as a university degree that is relatively transferable across firms and industries. Conversely, specific human capital strengthens an individual's knowledge about the idiosyncratic routines and procedures utilised in a particular firm. This is less easily transferred. For those who apply for an auditing licence, the auditing certificate constitutes a prerequisite for establishing their own business or becoming a partner in an auditing firm. In contrast, for those uninterested in public practice, the auditing certificate represents a professional qualification that could arguably expand labour market opportunities (Bullen and Flamholtz, 1985). Considering the highly fragmented nature of the audit market (Dillard and Ferris, 1989; Ramírez, 2001), we deem that the integration of the human capital and entrepreneurship frameworks is relevant in explaining some specificities of the auditing profession. Ultimately, this may be helpful in laying the groundwork for future research in this area.

\section{The setting}

\subsection{Legislative reform}

The 1951 Companies Act established the antecedents of the auditing function in Spain. Inspired by French legislation (Ramírez, 2001: 407), the Act required the appointment of shareholders (the so-called accionistas-censores) to investigate a firm's financial statements. As noted by Cubillo Valverde (1990: 303): 'As far as auditing is concerned, the 1951 Act was unfortunate. Instead of entrusting such a relevant function ... to the experts [the members of the ICJCE], the Act attributed to shareholders the role of auditors.' In this context, external audits were demanded in the case of conflict and audits performed by shareholders actually resulted in an exercise of 'fictitious auditing' (García-Benau et al., 1998: 89-90).

As this legal initiative brought about widespread dissatisfaction among qualified auditors (ICJCE,
1951, 1957, 1960), some legislative reforms further enforced auditing provisions (Pacheco, 2000). As far as firms listed on the stock market were concerned, the Decreto-Ley 7/1964 and its accompanying legislation established some requirements for mandatory audits. Notwithstanding this legislation, disputes around the meaning of an audit (Pont Mestres, 1991; García-Benau et al., 1998) as well as the qualifications of those engaging in public practice resulted in a marginalised audit function.

In 1986, Spain joined the European Economic Community and this involved further legislative reforms in the accounting and auditing domain, which the regulatory bodies had been trying to anticipate since 1979 (Bougen and Vázquez, 1997: 3 ). The creation of two new associations of auditors $^{2}$ in the early 1980 s brought to an end the monopoly of ICJCE members in the provision of auditing services. Importantly for our purpose, no major attempt was made to develop a cohesive and credible infrastructure and the resulting situation featured 'division and struggle' (Cea García, 1992: 349). As in Greece (Dedoulis and Caramanis, 2007: 16), using the notion of 'profession' to refer to the auditing practice in Spain during this period would be contentious. The process of legislative reforms concluded with the passing of the Audit Law in 1988.

\subsection{The economy}

During the military dictatorship of General Franco, the Spanish economy operated under the principles of state intervention and autarchy (Carrera et al., 2001). In this context, the state set the prices of a considerable number of goods (e.g. bread and sugar), thereby neglecting the role of market forces. Furthermore, state-owned enterprises exerted an imposing role on sectors ranging from banking to hospitality through to manufacturing.

The Spanish government enforced stiff reforms to make the country conform to the principles of a free economy. Such reforms paid off. According to the World Bank, Spanish gross domestic product increased by an average rate of $3.7 \%$ during 1976-1988, compared with $2.5 \%$ in the US and $2.8 \%$ in the UK. In a related vein, Spanish exports increased by an average rate of $6.0 \%$ during that period, the outflows of foreign direct investments grew by $14.0 \%$, and the inflows of direct foreign investments increased from an average of ESP 979.6bn during 1978-1986 to ESP 2,263.3bn during 1986-1989 (Bajo-Rubio and SosvillaRivero, 1994). In short, this booming of the Spanish

\footnotetext{
${ }^{2}$ The two new associations of auditors were the Registro de Economistas Auditores (REA, Register of Economists Auditors) and the Registro General de Auditores (REGA, General Register of Auditors).
} 
economy resulted in the Madrid Stock Market becoming the most profitable one in Europe in 1985 and 1986.

\subsection{The audit market}

Some international audit firms have operated in Spain since the 1920s (Carrera et al., 2001). However, most of the big audit firms started operations during the 1960s amid the enforcement of certain mandatory audit requirements for firms listed on the stock market (Decreto-Ley 7/1964). For example, Deloitte, Plender, Haskins \& Sells started operations in Madrid in 1964 (Stevens, 1981). In the case of Price Waterhouse, Jones (1995: 283) noted: 'In nations, such as Italy and Spain, where the national accountancy profession remained embryonic, Price Waterhouse made the greatest progress. It built up a strong local client base and recruited and trained members of the indigenous population as professional staff and partners, supported by expatriates.' Finally, some other audit corporations established strategic alliances with domestic firms; in 1963, Hispano Suiza de Revisión was founded to insource audit work from audit multinationals. In the 1970 s, Revisión signalled its partnership with Coopers \& Lybrand, S.A. by changing its brand to Revispana y Coopers \& Lybrand, S.A.

At the beginning of our observation period, the Big Eight firms operated in Spain. Furthermore, such firms usually employed ICJCE members. Our searches in the ICJCE's archives reveal that Price Waterhouse employed 89 members of the ICJCE; Arthur Andersen, 60; Peat Marwick Mitchell, 24; Ernst and Whinney, 19; Touche and Ross, 90; and Binder Dijker Otte \& Co., 4.

The demand for audit services increased in Spain from the start of our observation period. For example, the number of listed firms audited by members of the ICJCE increased dramatically between 1974 and 1976, from 401 to 698 firms $(74 \%)$. In a related vein, the number of requests for ICJCE members to offer their professional services in litigation increased from 60 to 111 between 1974 and 1976. The annual reports of the ICJCE also indicated continued expansion in audits for non-listed firms, state-owned enterprises, chambers of commerce, and regional authorities. Because of the increasing demand for audit services, the number of certified auditors doubled during our observation period.

For 'unlicensed auditors', that is, individuals breaking from the profession at the time of earning the necessary credentials, our search in the ICJCE's archives for the period under investigation shows that $44 \%$ (354 individuals) worked for the public sector: at different ministries $(31.5 \%$, 253 individuals), state-owned enterprises (7.5\%, 60 individuals), and universities (5\%, 41 individ- uals). The remaining 56\% of 'unlicensed auditors' worked for the private sector: $23.6 \%$ (190 individuals) at consultancy and audit firms, 7.5\% (60 individuals) in the financial sector, and 24.4\% (196 individuals) in sundry industries.

\subsection{Education}

Spanish higher education institutions were traditionally populated by the wealthy as well as by those living in cities that host a university centre (e.g. Madrid, Barcelona, Salamanca, and Santiago; see Vila and Mora, 1998). The advent of the Spanish democracy changed this situation; in the case of degrees in economics and business administration, the number of university centres increased from 15 in 1976 to 23 in 1988 (Gutiérrez and Ortega, 2007) and, hence, made such studies accessible to students lacking the necessary funding to pay for board and lodging outside their homes.

Spain has a number of different levels of university education. In the period 1976-1988, the Spanish higher education system offered three types of programmes: (i) short-cycle programmes, comprising three-year university degrees; (ii) long-cycle programmes, typically five-year university degrees, although the length of these programmes increases to six years for engineering and medical degrees; and (iii) postgraduate degrees, such as doctorates, implying a long-cycle education programme as a prerequisite, and consisting of doctoral courses plus the delivery of a doctoral thesis. Doctoral programmes targeted individuals aiming for a university career (Vila and Mora, 1998: 173). Expansion in the number of university centres during our observation period brought about significant increases in the number of individuals earning three-year university degrees (e.g. 1,734 individuals in 1978-1979 and 4,081 individuals in 1987-1988) and, to a much larger extent, five-year university degrees (e.g. 1,488 individuals in 1978-1979 and 7,088 individuals in 1987-1988; see Anuario INE, 1979, 1988). In terms of social reputation, six-year degrees in medicine, architecture, and engineering are still highly regarded by Spanish society (Vila and Mora, 1998).

\subsection{The public sector}

The Spanish public sector experienced dramatic changes following the advent of democracy in 1976. As a consequence of the legislative reforms that followed the approval of the Spanish Constitution of 1978, the public sector steadily changed its focus from being an instrument of General Franco's dictatorship to providing service to the citizens (García de Enterría, 2007). In turn, this involved changes in societal understandings of accountability. Whilst General Franco and his regime were only 'accountable before God and 
history' (De la Cierva, 1973), the President of the National Jury (Audiencia Nacional) said in 1981: 'Those entrusted to manage the goods of others either public or private - should render accounts of their activities' (quoted in Valverdú Calafell, 1984: 104). Such ideas, which were common in Western democracies, involved a complete reshuffle of the Internal Auditing Agency of the Public Sector in 1982 (IAAPS, Tribunal de Cuentas del Reino), and this enhanced the expectations of those willing to pursue an auditing career within the public sector.

\section{Hypotheses}

\subsection{General human capital}

Individuals with high levels of general human capital are expected to be more efficient in their jobs and enjoy a considerably greater number of labour market opportunities (Becker, 1962). Conversely, individuals with low levels of general human capital are regarded as less efficient in the workplace and are more likely to face spells of unemployment (Blaug, 1976). Accordingly, individuals who aim to increase their general human capital are prone to sacrifice current returns because of the expectation of higher future earnings (Mincer, 1962; Blaug, 1970). In view of such internal and external opportunities, these individuals are regarded as less likely than their counterparts to change their occupational status through selfemployment (Blanchflower and Oswald, 1998). Taken together, these results clearly reflect the decision to become an owner-manager as the default career choice.

Given the nature of the audit market (a professional services market), human capital can help explain the success or failure of auditing firms (Bröcheler et al., 2004). Auditors with a high level of educational attainment are expected to deliver consistent and high-quality services inside their firms (Pennings et al., 1998; Bröcheler et al., 2004). Several studies provided evidence on the relationship between general human capital and important characteristics of the audit market, such as the performance of auditing firms and the impact of human resources policies. ${ }^{3}$ Hunton and Wier (1996), for example, investigated the promotion of accountants working for private firms and found that attainment of education and professional certification - that is, general human capital exerted a significant, positive influence on the time-to-promotion decision. ${ }^{4}$ Moreover, Hunton and Wier (1996) found that professionally certified accountants were promoted more quickly than their non-certified counterparts.

These insights are relevant in understanding the characteristics of entrepreneurial activity in Spain. As a consequence of the highly interventionist economic model under Franco's dictatorship, not until the 1980s did an entrepreneurial culture begin to take root. Studies showed that Spanish entrepreneurs engage in entrepreneurial activities only through necessity, and seldom see such activities as an opportunity (Reynolds et al., 2001: 94). In other words, Spanish individuals perceive the decision to start a new business as the default career choice (Coduras et al., 2003: 34). This leads us to hypothesise:

H1: General human capital is negatively associated with the likelihood of newly certified Spanish auditors becoming licensed auditors.

\subsection{Specific human capital}

Mincer (1962) conceptualised specific training as an investment that increases the marginal product of those who invest in it by improving an individual's knowledge of workplace routines and procedures. As noted by Becker (1975), the idiosyncratic nature of specific human capital makes its transfer across organisations difficult. Individuals who acquire specific human capital engage in within-firm training programmes and have on-the-job experiences that increase their expectations of promotion and tenure, thereby providing little incentive for leaving the firm (Capelli and Cascio, 1991; Mincer, 1993).

Auditing firms face high levels of employee turnover, which affects their efficiency (Rhode et al., 1977; Rasch and Harrell, 1990). To curb this problem, auditing firms deploy internal, extensive, and compulsory training programmes that increase the expertise of their employees in a firm's routines and procedures, and ultimately result in the enhancement of specific human capital (Pennings et al., 1998). These training programmes are often regarded as part of a general programme of socialisation for individuals into the organisational culture, and therefore, 'they are first and foremost a commitment to an individual firm.' (AndersonGough et al., 1998: 3; 2002). Specific human capital helps to produce high-quality auditing services and decreases employee turnover as well as the likelihood of becoming self-employed in the auditing market (Robson et al., 1996; Lane and Parkin, 1998).

The Spanish audit market featured high uncertainty during our observation period. Despite prospects of growing demand for audits, several accounting scandals (e.g. in 1983, Explosivos Río Tinto) and a continuous conflict among auditors brought about societal and legal understandings of

\footnotetext{
${ }^{3}$ Given the dearth of studies on the impact of human capi tal on promotion within Spanish audit firms, we rely on inter national evidence, especially from the US and the UK.

${ }^{4}$ For example, accountants with a postgraduate education experienced faster promotion than those with a bachelor's de gree alone (Hunton and Wier, 1996).
} 
the audit function as an 'activity' instead of a 'profession' (Carrera, 2003). Furthermore, the future of auditing was highly dependent on the passing of specific regulation by the Spanish Parliament. Arguably, newly certified auditors with high specific human capital experienced conflicts between opportunities arising from the expected, growing demand for audit services and high uncertainty about the future of the profession. Under conflicting circumstances such as those featured by the Spanish audit market, Hofstede (1997) suggested that individuals draw heavily on their national culture to make decisions. In this respect, Spain scored highly (90) in Hofstede's index for uncertainty avoidance, that is, the Spanish society did not have tolerance for ambiguity and uncertainty (e.g. for comparison purposes, the UK scored 40 in this metric). Consequently, newly certified Spanish auditors with high specific human capital would have leaned towards pursuing their careers in their current firms and, hence, refrained from engaging in entrepreneurial activities that would have involved financial investments, high risks and high market uncertainty. Thus, we make the following hypothesis:

H2: Specific human capital is negatively associated with the likelihood of newly certified Spanish auditors becoming licensed auditors.

\subsection{Age}

The entrepreneurship literature contends that self-employment decisions are contingent on the age of the individual (Casson, 1982). Arguably, young people lack the experience, skills, and material resources to ensure successful entry into the entrepreneurial market (Blanchflower et al., 2001) and may use the auditing certificate as a formal endorsement of their professional qualifications. Therefore, it is expected that the decision to become an owner-manager is more likely to be made by older individuals (Carr, 1996; Blanchflower et al., 2001). Furthermore, individuals close to retirement tend to be risk-averse (Bates, 1990), suggesting they are reluctant to leave salaried work for the uncertainties of self-employment (Hachen, 1990). Legal and financial risks inherent in the auditing profession (Simunic and Stein, 1996; Dalton et al., 1997) add to the usual uncertainties of entrepreneurship. At the same time, the expectations of financial returns for older, newly certified auditors are lower because they are restricted to the remaining short period until retirement. Conversely, middle-aged individuals have accumulated work experience, knowledge of the market, and professional reputation (Knight, 1921; Brüderl et al., 1992). Furthermore, they can expect the returns from their entrepreneurial efforts over a relatively longer period before retirement. In addition, the middle-aged auditor is likely to have sufficient material resources to establish a new business and to tackle its concomitant financial and legal risks. Arguably, middle-aged, newly certified auditors are more likely than their younger and older counterparts to apply immediately for an audit licence and to become business owner-managers, either on their own or with a partner or partners.

In the case of Spain, Carrasco (1999) examined the transitions to and from self-employment by drawing on data gathered from an extensive database, the Spanish Continuous Family Expenditure Survey (Encuesta de Población Activa, ECPF) for the period 1985-1991. Carrasco (1999) focused on entrants into self-employment from wage earners and unemployed individuals and found that middle-aged individuals (35-55 years old) accounted for the majority of entrants in both situations, $57.71 \%$ and $51.46 \%$ respectively. Interestingly also, young individuals had a higher propensity to go entrepreneurial from wage-earning positions $(27.82 \%)$ than from unemployment $(17.39 \%)$. In the latter case, they probably lacked the necessary financial resources (Carrasco, 1999: 341). Taken together, this reasoning leads us to make the following hypothesis:

H3: Age has an inverted U-shaped relationship with the likelihood of newly certified Spanish auditors becoming licensed auditors.

\subsection{Switching costs: job stability}

The chances of starting a new business are negatively related to the costs of leaving an employment situation (Gimeno et al., 1997). Newly certified auditors assess their switching costs by comparing their current occupational status with the eventual ownership of a firm in the auditing market. The latter involves risks arising from client and third-party liability (e.g. Simunic and Stein, 1996; Dalton et al., 1997; Johnstone, 2000). People working in positions characterised by a high degree of stability, security, and insulation from external competition may consider this risk as being too high (Hachen, 1990).

Public sector employees provide a particularly strong example of switching costs because they enjoy long-term stability, regular salary, predictability, and an internal system of promotion (Hinchliffe, 1987). This is evidenced by low employee turnover in public sector jobs (Hachen, 1990). In Spain, the employment conditions of civil servants (funcionarios) are such that public sector employees enjoy high social status (GarcíaPérez and Jimeno, 2006). Consequently, Spain is one country where '... there are typically several hundred, even thousands, of applicants for each vacancy in the public sector, while some occupations in the private sector find it difficult to hire new employees' (García-Pérez and Jimeno, 2006: $10)$. 
This is particularly appropriate in describing the behaviour of certified auditors in Spain, a country whose nationals have a high level of risk aversion (Coduras et al., 2003) and uncertainty avoidance (Hofstede, 1997). As noted by some commentators, this makes individuals prefer a stable income in public sector-related activities rather than an uncertain, albeit potentially higher, income from selfemployment (Reynolds et al., 2001). For Spanish individuals therefore, 'there remains a strong preference for stable income in a state-owned company or in the public sector' (Reynolds et al., 2001: 40). During our observation period, public sector employees enjoyed stable income and a high social appreciation, which made it difficult for them to go entrepreneurial through applying for an auditing licence, especially in view of career prospects within the public sector as a consequence of the reshuffle of the IAAPS (Valverdú Calafell, 1984). Therefore, we would expect newly certified auditors in stable jobs, such as the public sector, to use their auditing certificate to enhance their chances of promotion within the public sector, rather than taking the high risk and high uncertainty route of applying for an auditing licence and becoming owner-managers in the audit market. Thus, we make the following hypothesis:

H4: Newly certified Spanish auditors with high switching costs from their present occupation have a lower likelihood of becoming licensed auditors.

\section{Data source, variables and methods}

\subsection{Data source}

Our research is based on information gathered from the archives of the ICJCE concerning their licensed and unlicensed members. The ICJCE's directories contain information about members' names, addresses, and dates of admission to the ICJCE, as well as their educational background, occupational status, previous positions, and eventual application for an auditing licence at the time of entry to the ICJCE. Our data are based on 2,633 individuals with completed entries who earned an auditing certificate between 1976 and 1988. Of these, 1,931 (73.34\%) registered as licensed auditors at the time of joining the ICJCE, and 702 $(26.66 \%)$ did not apply for an auditing licence (unlicensed auditors). ${ }^{5}$

\subsection{Methods}

We use logistic regression to model the likelihood of newly certified auditors becoming licensed auditors (Hosmer and Lemeshow, 1989). In auditing research, Dalton et al. (1997) used this model to examine the decision regarding the eventual withdrawal of a firm's partner to avoid litigation risks. What distinguishes a logistic regression model from a linear regression model is that the outcome variable (in our case, 'licensed auditors') is dichotomous. That is, the variable takes a value of 1 if the individual is a 'licensed auditor' and 0 if the individual is an 'unlicensed auditor'. Logistic regression models permit us to estimate the probability of an individual applying for an audit licence. Therefore, the probability of becoming a licensed auditor is:

$$
\text { (1) } \Pi(X)=\frac{e^{g(X)}}{1+e^{g(X)}} \text {, }
$$

where

$g(X)=\beta_{0}+\beta_{1} x_{1}+\beta_{2} x_{2}+\ldots+\beta_{p} x_{p}$,

$\Pi(X)=$ probability (licensed auditor),

$\beta_{0}$ is the estimated constant,

$\beta_{1}$ through to $\beta_{p}$ are the estimated coefficients, and

$\chi_{1}$ through to $\chi_{p}$ are the independent variables.

The estimated coefficients for the independent variables represent the slope or rate of change of the logit function of the dependent variable ('licensed auditors') per unit change in the independent variable. The interpretation of each coefficient relates directly to the definition and meaning of a one unit of change in the independent variable. ${ }^{6}$

\subsection{Operationalisation of variables}

\section{Audit licence}

As previously stated, the dependent variable Audit licence depicts the decision of the newly certified auditor to apply for an auditing licence and become a licensed auditor. This dichotomous variable was coded $1=$ licensed auditor and $0=$ unlicensed auditor. This categorisation is similar to the studies in the review by Amemiya (1981) of individual choices among labour market opportunities.

\section{Education}

Both human capital theory and the auditing literature used years of education and education level as proxies for general human capital (e.g. Carroll and Mosakowski, 1987; Carr, 1996; Hunton and Wier, 1996; Pennings et al., 1998). To categorise the variable Education, we need to consider both the entry requirements of the profession and the characteristics of the Spanish university system. In our sample, all individuals are certified auditors and, hence, hold a university degree or equivalent.

\footnotetext{
${ }^{5}$ The search in the ICJCE's archives located 802 unlicensed auditors for the period under investigation. One hundred ob servations were excluded from the analyses because of miss ing data.

${ }^{6}$ The intercept coefficient may also be of interest (Hosmer and Lemeshow, 1989). In our case, the intercept coefficient captures some factors affecting the probability of becoming a licensed auditor unmeasured by the variables included in the model.
} 
Accordingly, we categorise the Education variable as follows: $1=$ a three-year university degree; $2=$ a five-year university degree; and 3 = a postgraduate degree (e.g. $\mathrm{PhD}$ ).

\section{Big firms}

Large organisations are often characterised by considerable distances between units and employees. This brings about potential problems with standardising products and services, as well as maintaining internal cohesion. Consequently, large firms seek to acquaint their employees with routines and procedures, providing them with expansive in-house training programmes (AlbaRamírez, 1994). Large auditing firms provide their employees with more structured training to help enhance their competency and expertise in performing audits (Chia, 2003: 104). Empirical evidence on the training programmes of large auditing firms reveals a complex web of formal and informal rules that must be learned by individuals working for these organisations (AndersonGough et al., 1998; Grey, 1998; Pennings et al., 1998). However, the routines of small accounting firms are not as formally established, and employees acquire these through significant on-the-job exposure (Humphrey et al., 2006). In sum, auditors working for leading domestic or international auditing firms are expected to gain more specific human capital than their counterparts in smaller firms.

The Big firms variable was created to identify individuals working for large auditing firms at the time of affiliation with the ICJCE. This variable was coded $1=$ individual worked for a leading domestic or international auditing firm at the time of joining the ICJCE, and $0=$ individual did not work for such a firm.

Age

This variable is regularly employed in both the human capital and entrepreneurship literature (Becker, 1975; Rhode et al., 1977; Evans and Leighton, 1989; Carr, 1996). We employ a continuous variable to measure the individual's age in years at the time of joining the ICJCE. We hypothesise a quadratic or U-shaped relationship between the individual's age and the likelihood of engaging in auditing practice. Both the variable Age and its square value $(A g e S Q)$ are included to capture any non-linearity in the relationship (Hosmer and Lemeshow, 1989: 95).

\section{Public sector}

We used the dichotomy between the "public sector' and the 'private sector' as a proxy for stability and security. In this respect, our dichotomous variable, Public sector, is coded $1=$ individual was working in the public sector at the time of joining the ICJCE, and $0=$ individual did not work in the public sector.

\section{Control variables}

Previous research shows gender differences in the Spanish auditing market (Carrera, 2003). In fact, women were barred from the auditing profession by the ICJCE until 1976. Although the number of women in the ICJCE has increased every year since 1976, the number of men joining the ICJCE has remained significantly higher, ensuring that auditing remains a male-dominated profession (Carrera et al., 2001). Research on self-employment decisions show that women's decisions differ from men's: women, for instance, place greater emphasis on their families when making the entrepreneurial decision (Carr, 1996; Blanchflower and Oswald, 1998). Thus, we created a Gender variable, coded $1=$ female and $0=$ male .

The supply of auditing services depends on the number of auditors in the market (Pennings et al., 1998). In the case of the Spanish auditing market, auditor density is largely contingent on geographical distribution. The provinces of Madrid, Barcelona, Seville, Valencia, and Biscay reported the highest density of auditors during our observation period. Thus, we create the variable Market density to identify the province in which auditors established their offices and offered their professional services: $1=$ individual established in Madrid, Barcelona, Seville, Valencia, or Biscay; and $0=$ individual established elsewhere.

We argue that the decision to become a licensed auditor may also be influenced by contextual factors, such as expected changes and actual enforcement of auditing regulations, as well as by the general economic situation. Therefore, the moment an individual is granted an auditing certificate may constitute a relevant variable for explaining the likelihood of applying for an auditing licence. We created the variable Year of qualification as an indicator of the time the individual joined the ICJCE, establishing four subperiods in an attempt to capture significant changes in the Spanish auditing profession. First, we consider the period 1976-1979, which is characterised by a monopoly of ICJCE members in the provision of auditing services to firms established in Spain. Second, the period 1980-1983 witnessed the removal of this monopoly and the emergence of other professional associations (i.e. Registro de Economistas Auditores (REA)). Third, the period 1984-1987 is characterised by the actual challenge from auditors of other professional associations to ICJCE's members. Finally, we considered 1988 as the year when the Spanish Audit Law was discussed and passed in the Spanish parliament.

\section{Descriptive analysis and results}

\subsection{Descriptive analysis}

We conducted a preliminary analysis of the relationship between the dependent and independent 
variables. The univariate analysis revealed some degree of association between the variables included in our model and the probability of applying for an auditing licence. Table 1 presents the basic descriptive statistics and the correlation matrix for the variables included in the model. As shown in Table 1, the arithmetic means indicate that licensed auditors have a lower education level and are older than unlicensed auditors, and that the latter are more likely to work for the public sector. The correlation matrix shows that there are many significant correlations. However, these are of such a low magnitude that the potential for collinearity in our model is limited.

Table 2 describes the categorical variables included in the model (Education, Big firms, Public sector, Market density, and Gender). Data for the variable Education show that the highest percentage of licensed auditors is among those holding a three-year university degree (633 of 724 individuals or $87 \%$ are licensed auditors). For certified auditors with a five-year university degree, this percentage drops to $68 \%$ (1,242 of 1,817 individuals). In the case of the variable Big firms, we found that 308 individuals of the 491 working for large auditing firms are licensed auditors (approximately $63 \%$ ). For those who do not work for large auditing firms, the percentage is higher (about 80\%). The percentage of licensed auditors among those working for the public sector is around 50\% (277 of 554 certified auditors). In relation to the control variable Market density, Table 2 shows that $71 \%$ of individuals in provinces with a high density of auditors applied for an audit licence. For the variable Gender, the sample indicates that approximately $66 \%$ of women and $74 \%$ of men are licensed auditors. Lastly, the number of individuals becoming certified auditors diminished over the years (see Year); this is mainly because of the decline in the number of licensed auditors and, we argue, a decline in market growth. While in the cohort of 1976-1979, the proportion of individuals obtaining an audit licence was 81.7\% (770 of 943 individuals), in 1988 the percentage dropped to $71 \%$ (485 of 684 individuals). The variable Age was included in the model as a continuous variable and its basic statistics are also reported in Table 1.

\subsection{Results}

Model 1 in Table 3 shows the results of the multivariate logistic regression model for $\mathrm{H} 1-\mathrm{H} 4$. All variables other than Gender and the constant are significant at $\alpha=0.01$. The Hosmer-Lemeshow goodness-of-fit test indicates that the model is well suited to the data.

H1 states that the likelihood of newly certified auditors becoming licensed auditors is negatively associated with the level of general human capital. We would have support for this contention if the coefficients of the Five-year university degree and Post-graduate degree (master's degree or doctorate) variables were negative and significant. Model 1 in Table 3 reveals that both Five-year university degree and Post-graduate degree (master's degree or doctorate) variables have negative ( -0.724 and -0.758 , respectively) and significant ( $\alpha=0.01)$ coefficients. The estimated coefficients indicate that a change in the level of education (a higher education level than that existing in the control group Three-year university degree) has a negative impact on the likelihood of obtaining an audit licence. This finding indicates ceteris paribus that newly certified auditors with high general human capital were less likely to apply for an auditing licence and become business owner-managers in the audit market than their counterparts.

$\mathrm{H} 2$ contends that the likelihood of newly certified auditors becoming licensed auditors is negatively associated with their level of specific human capital. There is support for $\mathrm{H} 2$ if the coefficient of the Big firms variable is negative and significant. Model 1 reveals that the coefficient for Big firms is negative $(-0.884)$ and significant $(\alpha=0.01)$. Consequently, this finding indicates that newly certified auditors with high levels of specific human capital were less likely to apply for an auditing licence and become licensed auditors than their counterparts. All other things being equal, newly certified auditors who had been exposed to on-the-job training programmes in their firm (e.g. a large auditing firm) were less likely to apply for an auditing licence and become business ownermanagers through self-employment than their counterparts (e.g. those employed by small to medium-sized auditing firms).

$\mathrm{H} 3$ investigates the relationship between age and the likelihood of applying for an audit licence. H3 predicts that the decision of a newly certified auditor to become a licensed auditor exhibits an inverted U-shaped relationship with age. Our results show that both Age and AgeSQ are significant $(\alpha=$ 0.01 ), and suggest a concave relationship between age and the likelihood of applying for an audit licence to become a business owner-manager in the audit market. This finding is reinforced by the results of the estimated odds ratios for Age, as derived from Model 1.7 Figure 2 shows the adjusted odds ratios for Age and illustrates the differences in the likelihood of becoming a licensed auditor for individuals of different ages, with the propen-

\footnotetext{
${ }^{7}$ We use the odds ratios because they provide a straightfor ward comparison of the likelihood of the event of becoming a licensed auditor among individuals of different ages (Hosmer and Lemeshow, 1989). Furthermore, we calculate the adjusted odds ratios instead of the adjusted estimated probabilities to avoid the eventual confounding effects of other variables in cluded in our model.
} 


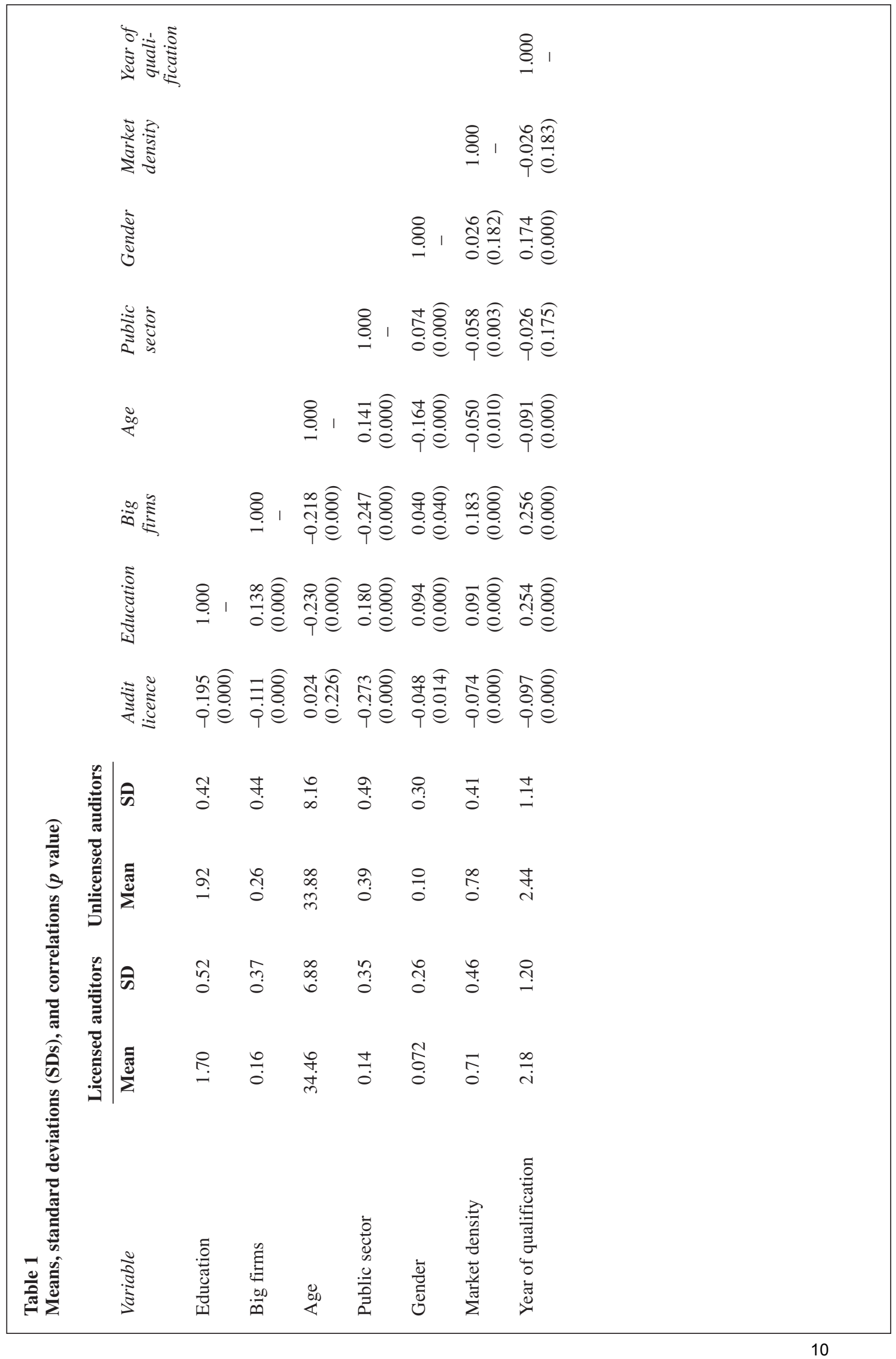


Table 2

Descriptive statistics for categorical variables

Variables

Education

Three year university degree

Five year university degree

Postgraduate degree

(master's degree or doctorate)

\section{Big firms}

No

519

(19.71\%)

Yes

183

$(6.95 \%)$

Public sector

No

425

(16.14\%)

Yes

277

(10.52\%)

\section{Market density}

High density: Madrid, Barcelona,

Seville, Valencia, and Biscay

Other

550
$(20.89 \%)$

152

$(5.77 \%)$

\section{Gender}

Male

Female

$$
630
$$$$
\text { (23.93\%) }
$$

72

(2.73\%)

\section{Year of qualification}

19761979

173

(6.57\%)

19801983

244

(9.27\%)

$19841987 *$

\section{6}

$(3.27 \%)$

1988
199

$$
\text { (7.56\%) }
$$

Licensed auditors $\mathrm{N}=1,931(73.34 \%)$

Total $\mathrm{N}=2,633(100 \%)$ 
Table 3

Logit analysis results to test for differences between licensed auditors and unlicensed auditors

Variable

Constant

Education

Five year university degree

Postgraduate degree

(master's degree or doctorate)

Big firms

Age

AgeSQ

Public sector

Gender

Market density

Year of qualification

19801983

19841987

1988

Age $\times$ Big firms

Pseudo $\mathrm{R}^{2}$

$\log \mathrm{L}$

LR Chi' (10)

$p>\mathrm{Chi}^{2}$

Standard errors are in parentheses

$* p=0.01$ (two tailed test)

$* * p=0.10$
Model 1 (Main effects)

Coefficient

$1.631 * *$

(0.964)

$0.724 *$

(0.139)

$0.758 *$

(0.262)

$0.884 *$

(0.135)

$0.241 *$

$(0.050)$

$0.003 *$

(0.001)

1.634*

(0.118)

0.010

(0.170)

$0.338^{*}$

(0.117)

$0.768 *$

(0.126)

$0.498 *$

(0.186)

$0.386^{*}$

(0.135)

Model 2

(Main effects and interaction) Coefficient

0.678

(1.013)

$0.752 *$

$(0.139)$

0.771 *

(0.300)

$3.522 *$

(0.743)

$0.199 *$

(0.052)

$0.003 *$

$(0.001)$

$1.601 *$

(0.118)

0.099

(0.171)

0.340 *

(0.117)

$0.778 *$

(0.126)

0.747 *

$(0.200)$

0.380 *

(0.136)

0.087 *

(0.024)

0.13

$1,325.52$

402.52

0.000
0.14

1,318.07

417.43

0.000 
Figure 2

Propensity to become a licensed auditor by age (adjusted odds ratios)

Propensity to become a licensed auditor (= 1 for individuals 33 years old)

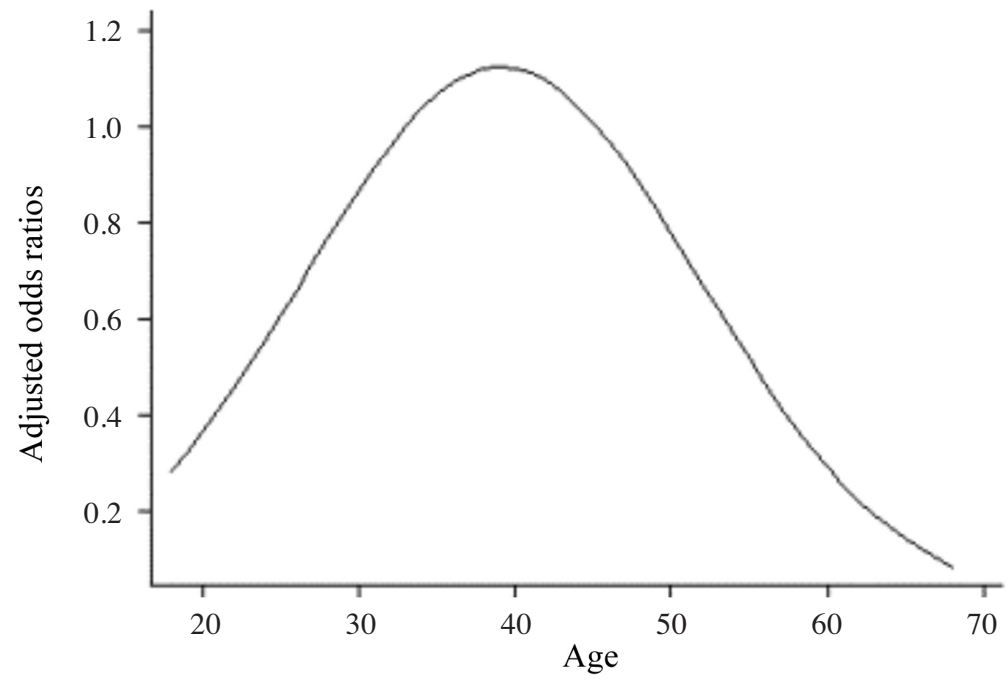

sity of individuals 33 years old being equal to one.

Figure 2 shows that middle-aged, newly certified auditors were more likely to apply for an audit licence than their younger or older counterparts. Our results show that the likelihood of becoming a licensed auditor increases until individuals reach 38-39 years, at which point a negative relationship exists between age and the propensity to become a business owner-manager in the audit market. Furthermore, we compare the propensity of a 33year-old certified auditor to become a business owner-manager in the audit market (propensity equal to 1) vis-à-vis their counterparts of other ages. Our results reveal that such a propensity was: (i) 0.6 among 25 -year-old individuals, (ii) 1.12 for 39 -year-olds, and (iii) 0.52 among 55-year-olds. In support of $\mathrm{H} 3$, our results indicate that younger and older newly certified Spanish auditors were less likely to apply for an audit licence and become business owner-managers.

H4 states that the likelihood of becoming a licensed auditor in Spain is negatively associated with the stability and security of the individual's job position at the time of becoming a certified auditor. Support for this contention requires the coefficient for Public sector to be significant and negative. Model 1 in Table 3 shows that the coefficient of the variable is negative $(-1.634)$ and significant $(\alpha=0.01)$. Ceteris paribus, this indicates that newly certified auditors working for the
Spanish public sector are less likely to apply for an audit licence than those working in the private sector. This suggests that the security and stability of the public sector jobs held by these individuals at the time of earning an audit certificate made them less likely to apply for an audit licence and become business owner-managers in the market for auditing services. ${ }^{8}$

With the exception of Gender and the intercept, the remaining control variables for both models are all significant at $\alpha=0.01$ (see Model 1, Table $3)$. The coefficients for the dummies of the variable Year of qualification are negative, suggesting that the likelihood of becoming a licensed auditor in the Spanish auditing market was smaller during the 1980s (subperiods 1980-1983, 1984-1987, and 1988) in comparison with the first subperiod, 1976-1979. However, this negative impact is proportionally smaller over time, indicating that individuals are more likely to apply for an audit licence and become business owner-managers at the end of the period under investigation than previously. The political stability of the 1980 s, the economic growth experienced by the country, and the expectations generated by the new regulations for the Spanish auditing market (e.g. the Audit

\footnotetext{
${ }^{8} \mathrm{~A}$ lack of skills and competence in managing an audit busi ness constitutes an equally plausible explanation. We thank an anonymous referee for this insight.
} 
Law was enacted in 1988) could partly explain this trend. Finally, the coefficient for Market density is significant and negative (see Model 1, Table 3). As expected, individuals were less likely to apply for an audit licence and become business owner-managers in the auditing market in regions with a higher number of potential competitors.

\subsection{Additional analysis}

One beneficial effect of specific human capital could be the increased likelihood of promotion into a partnership in an auditing firm, a position requiring a comprehensive knowledge of internal procedures and a commitment to the firm (Anderson-Gough et al., 1998). If the accumulation of specific human capital is not largely dependent on time and seniority (Becker, 1975), it would be difficult for auditing firms to provide intensive in-company training to employees while simultaneously delivering professional services to clients. Therefore, employees with greater seniority in auditing firms have arguably accumulated sufficient specific human capital to become eligible for promotion to partnership positions. In accountancy firms, a regular career from a junior accountant to a partnership position takes between 10 and 14 years (Robson et al., 1996; Expansión, 24 June 2004: 24). Promotion to a partnership position in these professional service firms makes an individual a business owner-manager. This produces a shift in their professional status.

Examination of the extent to which specific human capital is positively associated with the likelihood that newly certified auditors in Spain will apply for an audit licence to obtain promotion to a partnership position in an auditing firm requires the calculation of the joint effects of a newly certified auditor working for a large auditing firm and seniority. As the database does not contain data about the length of time that newly certified auditors had worked for the same firm, the Age variable is used as a proxy for seniority. Consequently, we measure the joint effects through the interaction term Age $\times$ Big firms, and support for our contention requires a positive, significant coefficient. We also expect a significant and negative coefficient for Big firms, as per Model 1. As the logistic regression shown in Model 1 does not adequately capture the interaction between variables, we estimate Model 2 (see Table 3). We find that both Big firms and Age $\times$ Big firms are significant $(\alpha=0.01)$. Furthermore, we find the expected signs for both coefficients: negative (-3.522) for Big firms and positive (0.087) for Age $\times$ Big firms. Arguably, the existing high correlation between this interaction term and Big firms (0.982) may generate multicollinearity and a loss of significance for some variables (Capelli and Cascio, 1991). However, the inclu- sion of this variable does not involve a loss of significance for the Big firms coefficient. The model remains well fitted to the data, as shown by the Hosmer-Lemeshow goodness-of-fit test. Our results indicate a positive relationship between the process of becoming a licensed auditor and employment with a large auditing firm when considering age at the time of joining the ICJCE. Finally, the remaining coefficients for both the independent and the control variables are similar to those shown in the model without the interaction parameters (Model 1).

We calculate the adjusted odds ratios to explore further the relationship between Age and Big firms. The adjusted odds ratios measure the likelihood of a newly certified auditor working for a large auditing firm becoming a licensed auditor (see Figure 3).

As shown in Figure 3, the adjusted odds ratios depict different patterns for each group of individuals. Newly certified auditors who did not work for a large auditing firm showed a declining likelihood of becoming business owner-managers between the ages of 40 and 45 years. After the age of 45 years, however, auditors working for large auditing firms were increasingly likely to obtain their auditing licences. For such individuals, this result is consistent with the relationship between age and promotion to partnership positions, which require the holding of an audit licence.

\section{Discussion and conclusions}

In this study, we focus on the characteristics of individuals joining the Spanish auditing profession during a relevant period of its history, namely, 1976-1988. This observation period had good prospects for auditors, because of market growth, and high uncertainty arising from the eventual consequences of a comprehensive reorganisation of the profession, ultimately enforced through state regulation. In this unique social laboratory, we examine the most significant asset in the audit market: human capital (Bröcheler et al., 2004). By focusing on the individual auditor as a unit of analysis, our study adds to prior research examining the emergence of the profession in continental European countries from a macro-perspective (e.g. professional associations or the profession at large; see Russia: Sucher and Bychkova, 2001; Slovakia: Daniel et al., 2001).

Our results indicate that Spanish newly certified auditors (i) with high general human capital, (ii) with high specific human capital, (iii) with stable jobs and (iv) at the beginning or end of their professional careers were less likely to apply for an audit licence than their counterparts with low general human capital, low specific human capital, unstable jobs, and who were middle-aged. According to human capital theory (Becker, 1975; Blaug, 
Figure 3

Adjusted odds ratios for the variables Age and Big firms

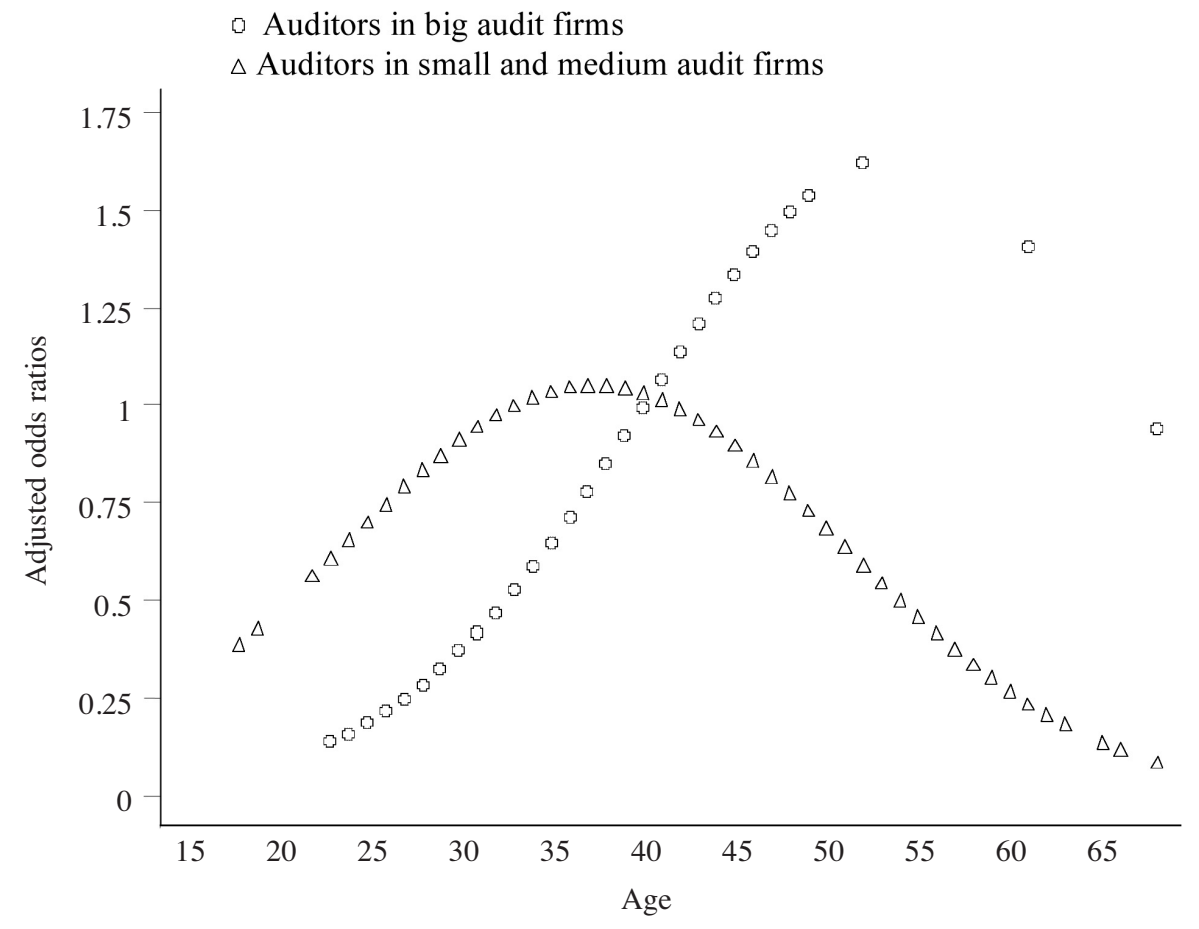

1976), individuals with high human capital outperform their counterparts with lower human capital. Therefore, our results reveal that the decision of newly certified Spanish auditors to engage in public practice constituted a default career choice (Mincer, 1962; Blaug, 1970, 1976). Some distinctive features of our context may help explain these findings.

The marketability of professional certifications such as Certified Public Accountant (CPA) or Chartered Accountant (CA) may seem inarguable to an English-speaking audience. Nonetheless, we advise caution when considering the market value of the audit certification in other settings; Spain had no tradition in auditing and mandatory audits were not actually enforced until very recently. Good prospects for growth in the Spanish audit market did not outperform perceptions of high uncertainty arising from the upcoming reforms, which would determine the future of the audit function. Furthermore, the history of professional associations such as the ICJCE provided support for contentions about a failure in the 'professionalisation process' of auditing in Spain (Bougen and Vázquez, 1997). As noted by Carrera (2003) the audit function was not considered a 'profession' in Spain but a mere 'activity'. Consequently, doubtful marketability of the audit certificate and failure in the audit professionalisation process did not at- tract to public practice newly certified auditors with high human capital, stable jobs and at the younger or older end of the age continuum, that is, those considered as 'talented' by human capital theory (Bröcheler et al., 2004).

During our observation period, a feature of Spanish society was the imposing role of the government in the economy (Carrera et al., 2001) and high levels of uncertainty avoidance (Hofstede, 1997). Furthermore, public sector employees enjoyed a high social status (García Pérez and Jimeno, 2006) because their jobs involved longterm stability, regular salary, predictability, and an internal system of promotion (Hinchliffe, 1987). Such values, which were highly regarded by Spanish society, imposed considerable switching costs on individuals with stable jobs, such as public sector employees; $79 \%$ of such individuals, upon completing the examinations leading to the audit certificate, did not apply for an audit licence. Arguably, the joint effects of high legal and financial risks inherent in public practice and high uncertainty avoidance in Spanish society discouraged those with stable jobs from being entrepreneurial and, hence, they remained in their stable income and long-term jobs (Reynolds et al., 2001: 40). Such decisions could also be a result of civil servants' good career prospects; societal claims for public sector accountability boosted its demand 
for auditors (Valverdú Calafell, 1984).

Within a context featuring environmental upheaval and good market prospects, our results reveal that factors related to uncertainty outweighed those connected to market opportunities. Consequently, middle-aged professionals with unstable jobs and low general and specific human capital constituted the most likely candidates to apply for auditing licences. However, newly certified auditors with high general and specific human capital, job security, and at the extremes of the age continuum declined engagement in audit practice after earning the audit certificate. In the case of high profile individuals, the turbulent conditions experienced by the auditing profession during the 1976-1988 period and the high uncertainty avoidance of Spanish society arguably offset the prospects for career opportunities coming from market growth and, ultimately, influenced their decision not to become business owner-managers.

The current study examines the unique social conditions featured by Spain during 1976-1988, that is, during the transition from a right-wing military dictatorship to a fully-fledged democracy. Consequently, the approach and findings of this investigation may be useful to time-space intersections featuring similar characteristics. In this respect, further research in this area might capitalise on some of the limitations of the present study. Our paper investigates the auditor's decision as to whether or not to become a licensed auditor at the time of entry into the profession. It would be interesting to extend the analysis over the professional life of certified auditors to gain a better understanding of the demography of the audit market. We used educational background and the contractual relationship with large auditing firms as proxy variables for human capital. Although such proxies were consistently employed in the human capital literature, other proxies, such as a firm's investment in training, may provide additional insights into the role of human capital in auditing firms.

\section{References}

Alba Ramírez, A. (1994). 'Formal training, temporary con tracts, productivity and wages in Spain'. Oxford Bulletin of Economics and Statistics, 56(2): 151170.

Amemiya, T. (1981). 'Qualitative response models: A sur vey'. Journal of Economic Literature, 19(4): 14831536. Anderson Gough, F., Grey, C. and Robson, K. (1998). Making up accountants. The organizational and profes sional socialization of trainee chartered accountants. England: Ashgate Publishing Ltd.

Anderson Gough, F., Grey, C. and Robson, K. (2002). 'Accounting professionals and the accounting profession: Linking the conduct and context'. Accounting and Business Research, 32(1): 4156.

Anuario INE (1979). Anuario estadístico de España 1979. Madrid: Instituto Nacional de Estadística.

Anuario INE (1988). Anuario estadístico de España 1988.
Madrid: Instituto Nacional de Estadística.

Bajo Rubio, O. and Sosvilla Rivero, S. (1994). 'An econo metric analysis of foreign direct investment in Spain, 1964 89', Southern Economic Journal, 61: 104120.

Bates, T. (1990). 'Entrepreneur human capital inputs and small business longevity'. The Review of Economics and Statistics, 72(4): 551559.

Becker, G.S. (1962). 'Investment in human capital: a theo retical analysis'. Journal of Political Economy, 70(5): 949.

Becker, G.S. (1975). Human capital A theoretical and empirical analysis, with special reference to education. Second edition. New York, NY: Columbia University Press.

Blanchflower, D.G. and Oswald, A.J. (1998). 'What makes an entrepreneur?' Journal of Labour Economics, 16(1): 2660 .

Blanchflower, D.G., Oswald, A.J. and Stutzer, A. (2001). 'Latent entrepreneurship across nations'. European Economic Review, 45(4/6): 680691.

Blaug, M. (1970). An introduction to the economics of ed ucation. London: Allen Lane The Penguin Press.

Blaug, M. (1976). 'The empirical status of human capital theory: a slightly jaundiced survey'. Journal of Economic Literature, 14(3): 827855.

Bougen, P. (1997). 'Spain, July 1988. Some observations on becoming professional'. Accounting, Organizations and Society, 22(8): 757777.

Bougen, P. and Vázquez, D. (1997). 'Debating Spanish audit legislation: the audit law of 1988'. European Accounting Review, 6 (1): 117.

Bröcheler, V., Maijoor, S. and Witteloostuijn, A. (2004). 'Auditor human capital and audit firm survival. The Dutch audit industry in 1930 1992'. Accounting, Organizations and Society, 20: 627646.

Brüderl, J., Preisendörfer, P. and Ziegler, R. (1992). 'Survival chances of newly founded business organiza tions'. American Sociological Review, 57(2): 227242.

Bullen, M.L. and Flamholtz, E.G. (1985). 'A theoretical and empirical investigation of job satisfaction and intend ed turnover in the large CPA firms'. Accounting, Organizations and Society, 10(3): 287302.

Capelli, P. and Cascio, W.F. (1991). 'Why some jobs com mand wage premiums: a test of career tournament and in ternal labour market hypotheses'. Academy of Management Journal, 34(4): 848868.

Caramanis, C.V. (1998). 'Assessing the impact of "liberal isation" on auditor behaviour. Accounting research in politically charged contexts'. Accounting, Auditing and Accountability Journal, 11(5): 562592.

Caramanis, C.V. (2002). 'The interplay between profes sional groups, the state and supranational agents: Pax Americana in the age of "globalisation"'. Accounting, Organizations and Society, 27(4 5): 379408.

Carr, D. (1996). 'Two paths to self employment? Women's and men's self employment in the United States, 1980'. Work and Occupations, 23(1): 2653.

Carrasco, R. (1999).'Transitions to and from self employ ment in Spain: An empirical analysis'. Oxford Bulletin of Economics and Statistics, 61(3): 315341.

Carrera, N., Gutiérrez, I. and Carmona, S. (2001). 'Gender, the state and the audit profession: Evidence from Spain (1942 1988)'. European Accounting Review, 10(4): 803815.

Carrera, N. (2003). Ejercicio profesional, empresas y mer cado de auditoría. Doctoral Thesis, University Carlos III, Madrid, Spain.

Carroll, G.R. and Mosakowski, E. (1987). 'The career dy namics of self employment'. Administrative Science 
Quarterly, 32(4): 570589.

Casson, M. (1982). The entrepreneur. Oxford: Martin Robertson \& Company Ltd.

Cea García, J.L. (1992). 'Official auditors register and the professional bodies'. In J.A. Gonzalo (Ed.), Accounting in Spain. Madrid: Asociación Española de Contabilidad y Administración de Empresas.

Chia, Y.M. (2003). 'Career drivers of junior auditors: an exploratory study'. Managerial Auditing Journal, 18(2): 100111.

Coduras, A., López García, P., Justo, R. and De la Vega, I. (2003). Global Entrepreneurship Monitor: Informe Ejecutivo 2003 España. Madrid: Cátedra Najeti, Instituto de Empresa.

Cubillo Valverde, C. (1990). 'La reforma contable en España'. Revista Española de Financiación y Contabilidad, XX(63): 301315.

Dalton, D.R., Hill, J.W. and Ramsay, R.J. (1997). 'The threat of litigation and voluntary partner/manager turnover in Big Six Firms'. Journal of Accounting and Public Policy, 16(4): 379413.

Daniel, P., Suranova, Z. and De Beelde, I. (2001). 'The de velopment of accounting in Slovakia', European Accounting Review, 10(2): 343359.

DeAngelo, L.E. (1981). The auditor client contractual relationship. An economic analysis. Michigan: UMI Research Press.

De Beelde, I. (2002). 'Creating a profession "out of noth ing"? The case of the Belgian auditing profession'. Accounting, Organizations and Society, 27(4 5): 447470.

De la Cierva, R. (1973). Francisco Franco: Un siglo de España. Barcelona: Editora Nacional.

Dedoulis, E. and Caramanis, C. (2007). 'Imperialism of in fluence and the state profession relationship: The forma tion of the Greek auditing profession in the post WWII era'. Critical Perspectives on Accounting, 18(4): 393412. Dillard, J.F. and Ferris, K.R. (1989). 'Individual behaviour in professional accounting firms: a review and synthesis'. Journal of Accounting Literature, 8: 208234.

Evans, D.S. and Leighton, L. (1989). 'Some empirical as pects of entrepreneurship'. American Economic Review, 79(3): 519535.

Evans, L. and Honold, K. (2007). 'The division of expert labour in the European audit market: The case of Germany', Critical Perspectives on Accounting, 18: 6188.

Expansión (2004). Tres mil aspirantes están a la espera del examen para ser auditor en España Alumnos impa cientes. 24 June 2004 (p. 24).

García de Enterría, E. (2007). Administración española. Madrid: Civitas.

García Benau, M.A., Ruiz Barbadillo, E. and Vico Martínez, A. (1998). Análisis de la estructura del merca do de servicios de auditoría en España. Madrid: Instituto de Contabilidad y Auditoría de Cuentas.

García Benau, M.A., Ruiz Barbadillo, E., Humphrey, C. and Al Husaini, W. (1999). 'Success in failure? Reflections on the changing Spanish audit environment'. European Accounting Review, 8(4): 701730.

García Pérez, I. and Jimeno, J.F. (2006). 'Public sector wage gaps in Spanish regions'. Working Paper WP ECON 06.10, University Pablo de Olavide, Seville, Spain.

Gimeno, J., Folta, T.B., Cooper, A.C. and Woo, C.Y. (1997). 'Survival of the fittest? Entrepreneurial human capital and the persistence of underperforming firms'. Administrative Science Quarterly, 42(4): 750783.

Grey, C. (1998). 'On being a professional in a Big Six Firm'. Accounting, Organizations and Society, 23(5/6):
569587

Gutiérrez, I. and Ortega, J. (2007). 'Higher education in the business fields: the case of Spain'. In Durand, T. and Dameron, S. (Eds.), The future of business schools, Hampshire: Palgrave. In press.

Hachen, D.S. (1990). 'Three models of job mobility in labor markets'. Work and Occupations, 17(3): 320354.

Higson, A. (1997). 'Developments in audit approaches: from audit efficiency to audit effectiveness?' In M. Sherer, \& S. Turley (Eds.), Current issues in accounting. Third edition. London: Paul Chapman.

Hinchliffe, J.K. (1987). 'Public sector employment and education'. In G. Psacharopoulos (Ed.), Economics of ed ucation. Research and studies. Oxford: Pergamon Press.

Hofstede, G. (1997), Cultures and Organizations: Software of the Mind. London: McGraw Hill.

Hosmer, D.W. and Lemeshow, S. (1989). Applied logistic regression. Canada: John Wiley \& Sons, Inc.

Humphrey, C., Jones, J., Khalifa, R. and Robson K. (2006). 'Business risk auditing and the auditing profession: status, identity and fragmentation', Accounting, Organizations and Society, 32(4/5): 409438.

Hunton, J.E. and Wier, B. (1996). 'Performance of ac countants in private industry: a survival analysis'. Accounting Horizons, 10(3): 5477.

ICJCE (1951). Memoria Anual 1951. Madrid: Instituto de Censores Jurados de Cuentas de España.

ICJCE (1957). Memoria Anual 1957. Madrid: Instituto de Censores Jurados de Cuentas de España.

ICJCE (1960). Memoria Anual 1960. Madrid: Instituto de Censores Jurados de Cuentas de España.

Johnstone, K.M. (2000). 'Client acceptance decisions: si multaneous effects of client business risk, audit risk, au ditor business risk, and risk adaptation'. Auditing: A Journal of Practice \& Theory, 19(1): 125.

Jones, E. (1995). In True and Fair: A History of Price Waterhouse. London: Hamish Hamilton.

Knight, F.H. (1921). Risk, uncertainty and profit. New York, NY: Sentry Press.

Lafuente, A. and Salas, V. (1989). 'Types of entrepreneurs and firms: The case of new Spanish firms'. Strategic Management Journal, 10: 1730.

Lane, J. and Parkin, M. (1998). 'Turnover in an accounting firm'. Journal of Labour Economics, 16(4): 702717.

Margerison J. and Moizer, P. (1996). 'Auditor licensing in the European Union: a comparative study based on cul tural differences'. European Accounting Review, 5(1): 2956.

Mincer, J. (1962). 'On the job training: costs, returns, and some implications'. Journal of Political Economy, 70(5): 5079.

Mincer, J. (1993). 'Human capital responses to technolog ical change in the labor market'. In Collected essays of Jacob Mincer, Vol. 1, Studies in Human Capital. Economists of the Twentieth Century Series: 345365. U.K.: Elgar.

Pacheco, M. (2000). Régimen legal de la auditoría de cuentas y responsabilidad de los auditores. Consejo Económico y Social: Colección Estudios, No. 92, Madrid. Pennings, J.M., Lee, K. and Witteloostuijn, A.V. (1998). 'Human capital, social capital, and firm dissolution'. Academy of Management Journal, 41(4): 425440.

Pont Mestres, M. (1991). Al servicio de la profesión audi tora. Madrid: Instituto de Censores Jurados de Cuentas de España.

Preisendörfer, P. and Voss, T. (1990). 'Organizational mor tality of small firms: the effects of entrepreneurial age and human capital'. Organization Studies, 11(1): 107129.

Ramírez, C. (2001). 'Understanding social closure in its 
cultural context: Accounting practitioners in France (1920 1939)'. Accounting, Organizations and Society, 26(4): 391418.

Rasch, R.H. and Harrell, A. (1990). 'The impact of person al characteristics on the turnover behavior of accounting professionals'. Auditing: A Journal of Practice \& Theory, 9(2): 90102.

Reynolds, P., Hay, M., Bygrave, W.D., Camp, S.M. and Autio, E. (2001). Global Entrepreneurship Monitor. 2001 Executive Report. Kansas City: Kauffman Center for Entrepreneurial Leadership at the Ewing Marion Kauffman Foundation.

Rhode, J.G., Sorensen, J.E. and Lawler III, E.E. (1977). 'Sources of professional staff turnover in public account ing firms revealed by the exit interview'. Accounting, Organizations and Society, 2(2): 165175.

Robson, G.S., Wholey, D.R. and Barefield, R.M. (1996). 'Institutional determinants of individual mobility: bring ing the professions back in'. Academy of Management Journal, 39(2): 397420.
Seal, W., Sucher, P. and Zelenka, I. (1996). 'Post Socialist transition and the development of an accountancy profes sion in the Czech Republic'. Critical Perspectives on Accounting, 7: 485508.

Simunic, D.A. and Stein, M.T. (1996). 'The impact of liti gation risk on audit pricing: a review of the economics and the evidence'. Auditing: A Journal of Practice \& Theory, 15(2): 119134.

Stevens, M. (1981). The Big Eight. New York, NY: Macmillan Publishing Company.

Sucher, P. and Bychkova, S. (2001). 'Auditor independ ence in economies in transition: a study of Russia'. European Accounting Review, 10(4): 817841.

Valverdú Calafell, J. (1984). 'Las finanzas públicas y su control. El Tribunal de Cuentas y la auditoría contable'. Revista Española de Financiación y Contabilidad, XIII(44): 317342.

Vila, L.E. and Mora, J.G. (1998). 'Changing returns in ed ucation in Spain during the 1980s'. Economics of Education Review, 17(2): 173178. 